\title{
Nicoleta CORBU*
}

\section{Book review of The Emotions Industry edited by Mira Moshe, New York: Nova Publishers, 2014, 265 pages}

Mira Moshe's edited book The Emotions Industry is the author's second book dedicated to the sociology of emotions. Placed in the theoretical tradition of the Frankfurt's school, the book investigates a complex cultural phenomenon, in the wake of Adorno and Horkheimer's seminal work on the "culture industry". Moshe believes that the consumption society purposefully exaggerates emotions, in order to obtain social, cultural and economic wealth. She posits that media plays a key role in the very nature of the emotions industry by generating, strengthening, and encouraging "emotional trade".

Building on theories and concepts such as emotional trade-off (Homans, 1961), emotional capital as a source of educational opportunities (Allat, 1993; Reay, 1998, 2000), the main argument of the book relies on the Frankfurt School's main assumptions. As the editor writes in the Introduction, "cultural production whose origins can be traced to the emotional manipulation of media and entertainment consumers and encouraging the masses to passivity (Adorno \& Horkheimer, 1972; Adorno \& Horkheimer, 2007) has developed into an industry focusing on creating a false aesthetic and blurring the boundaries between culture and real life (Adorno, 2005)" (p. ix). Media's role is thus to blur the boundaries between the original and the reproduction, to promote pseudo-authenticity by appealing to public's emotions.

The book gathers together contributions of researchers from all over the world (Israel, USA, Finland, Italy, Brazil, Romania, and Australia), thus offering various angles of interpretation of the investigated phenomenon.

In the first section, The Emotions Industry - The Construction of a Romantic Production Line, Mira Moshe, Julia Meszaros, Amir Hetsroni and Abira Reizer analyze media representations of romance. From emotional branding involving love and family to the romance tourism industry and afterwards to topics of conflict in romantic relationships, this section offers a general approach to the mediatization of romance, trying to explain the subtle mechanisms through which a sense of intimacy and belonging is created in order to convert them into selling experiences.

The second section covers topics related to the production and consumption of emotional content. The three chapters included in this section focus on three different types of media in order to suggest culturally sensitive ways of attracting audience, by appealing to emotions: amateur photography in Finnish journalism, television reality-shows in Italy, and ultra-Orthodox Jewish feature films in Israel. As far as the amateur photography is concerned, its main purpose in a consumption society has become to elicit strong emotional excitation in order to induce the feeling of "being there" in the audience. From a different perspective, the TV reality shows have the power of creating the illusion that a virtual community could success-

${ }^{*}$ College of Communication and PR, National University of Political Studies and Public Administration, nicoleta.corbu@comunicare.ro. 
fully replace a real one, by means of producing emotional responses into the audience. The analysis of the women dedicated ultra-Orthodox movies offer an inside perspective on the "apparatus by which producers focus on viewers' emotional experiences using religion as an exciting commercial product and attempt to design an active cinematic viewing experience for participants" (p. xii).

Fear and death in the media are covered in the following section. The two chapters cover the emotions industry based on negative feelings, from anxiety to fear, self-recrimination, and dissatisfaction. In chapter seven, Shirly Bar-Lev analyzes the emotional codes embedded in the on-line communication on the verge of death. Fear is further examined in chapter eight through frightening visual content consumed by Israeli and American children.

Section four, "The Emotions Industry: The Politics of Emotion" offers two culturally based approaches to politics, from the point of view of the spectacle of politics built on exploiting emotions. Adrian Scribano and Mira Moshe show how sports can be emotionally used in political marketing, while Florenta Toader offers insights from the online communication in Romanian politics.

The last section of the book deals with self-exposure in the emotions industry. The topics covered in the three chapters vary from marketing celebrities by means of entertainment magazines and ethical representations of emotions and fame, to the re-interpretation of Simmel's theory regarding fashion.

The coherence of the book resides in its general approach to the emotions industry from various angles and cultural perspectives. The book is unique from this point of view: it offers a multi-faceted insight into what has nowadays become the classical concept of "culture industry", from the perspective of the sociology of emotion.

The reader has thus the opportunity to have new insights into the mechanisms of production and distribution of emotions, with the purpose of accumulating social, cultural, and economic wealth.

Mira Moshe's second edited book dedicated to the sociology of emotions places her among the prominent scholars preoccupied with cross-cultural approaches to emotional phenomena. This book is situated at the crossroads of sociology of emotions, critical communication studies, and cultural studies, which makes it interesting and appealing to scholars from various fields of studies.

\section{References}

1. Adorno, T. \& Horkheimer, M. (1972). Dialectic of enlightenment, Translated by J. Cumming. New York: Herder \& Herder.

2. Adorno, T. \& Horkheimer, M. (2007). The Culture Industry: Enlightenment as mass deception. In S. Holmes \& S. Radmond (Eds.), Stardom and celebrity: A reader (pp. 34-43). London: Sage.

3. Adorno, T. (2005). The culture industry: Selected essays on mass culture J. M. Bernstein (Ed). London: Routledge.

4. Allatt, P. (1993). Becoming privileged: The role of family processes. In Youth and inequality, I. Bates \& G. Riseborough (Eds.), 139-59. Buckingham: Open University Press.

5. Homans, G. (1961). Social behavior: Its elementary forms. New York: Harcourt Brace Jovanovich.

6. Reay, D. (1998). Class work: Mothers' involvement in their children's primary schooling. London: University of London Press. 